Syntax Literate: Jurnal Ilmiah Indonesia p-ISSN: 2541-0849

e-ISSN: 2548-1398

Vol. 5, No. 7, Juli 2020

\title{
AN ANALYSIS OF FIGURATIVE LANGUAGE IN JALALUDDIN RUMI'S QUOTES IN BOOK THE MEANINGFUL LIFE WITH RUMI
}

\author{
Imam Soekarno Putra and Anita Puspitasari \\ Sekolah Tinggi Bahasa Asing (STBA) Cipto Hadi Pranoto \\ Email: imamsoekarno90@gmail.com and anita.puspitasari@gmail.com
}

\begin{abstract}
This research is aimed to know and comprehend about figurative language which is used by Jalaluddin Rumi's quotes. The main problem in this research are to know kinds of figurative language, literal meaning and the dominant of figurative language are found in Jalaluddin Rumi's quotes. The primary source is from book "The meaningful life with Rumi" which was edited by Abd. Kholiq. There are 212 quotes on it which contain poems and proverbs. The writer analyzes 60 quotes. The second data source is taken from Laurence Perrine, Gorys Keraf and others that are related to the things which are going to be analyzed. This research uses qualitative research method. The data are collected, classified, identified and explained by giving the evidence from the statements. The writer only focuses four types of figurative language that are metaphor, personification, overstatement, and simile. Based on the result of this research, the writer concludes that in Jalaluddin Rumi's quotes uses figurative language and there is literal meaning. The writer also has found 75 figurative language in Jalaluddin Rumi's quotes from 60 quotes in the book of "The Meaningful Life with Rumi". The writer has concluded the most of dominant figurative language which is utilized in Jalaludin Rumi's quotes is metaphor with the total 23 statements, the second is simile with the total 22 statements, the third is overstatement with the total 16 statements and the last is personification with the total 14 statements. The most of Jalaluddin Rumi's quotes talk about love, faith, hope, soul, virtue and determination.
\end{abstract}

Keywords: Figurative language; Jalaluddin Rumi's quotes and Literal meaning.

\section{Introduction}

In interacting among society, People use language as device to communicate to each other. Hence, language is one of the most important devices used in communication among human being. Through the language, people are able to convey all information, ideas, and concepts that are needed. According to (Delahunty \& Garvey, 2010) explains that a language is a set of rules, unconsciously present in the mind, which enables human beings to represent and communicate meanings by producing audible, visible, or tactile symbols that these rules systematically relate to those meanings.

Talking about communication and language, they will not be separated with the spoken language which the speakers use to interact to others. The world's most widely spoken language is currently English which has a very important role in the work. 
According to Wellek and Warren (1989) Literature and language are two fields that cannot be separated. The relationship between literature and language is dialectical. Division of literary work that has been known three, prose, poetry, and drama. All types of literature is using beautiful words to be interesting. Equation principal three are using of language as a means of delivery.

One of the literary works is poetry. "Poetry is as universal as language and almost as ancient" (Perrine, 2000) Poetry can be many things, it can be philosophical, or emotional, or sentimental. It may paint pictures, in a descriptive mode, or tell stories, in a narrative one. Poetry can also be satirical, or funny, or political, or just informative. In the study of literature particularly poetry, we can find at least two substances, there are intrinsic and extrinsic elements. First element of poetry is related to denotation and connotation, imagery, figurative language such as simile, metaphor, personification, apostrophe, synecdoche, metonymy, symbol, allegory, paradox, overstatement, understatement and irony. Secondly is to unveil the author's interesting biography, the social life, mental, moral and intellectual growth. Biography can also be defined as the systematic study about the author's psychological and creative process.

An understanding about the meaning of phrases and sentences in analyzing literary works such as poetry is obviously necessary. It can help the reader to get the points, messages or knowledge that contained in the context. In consequence, the comprehension about figurative language form that widely used in literary works will help the reader to understand what the message from the context is.

Furthermore, Proverbs is also one of the literary quotes. According to whiting (Mieder, 2004). A proverb is an expression which, owing its birth to the people, testifies to its origin in form and phrase. It expresses what is apparently a fundamental truth that is, a truism, in homely language, often adorned, however, with alliteration and rhyme. It is usually short, but need not be; it is usually true, but need not be. Some proverbs have both a literal and figurative meaning, either of which makes perfect sense; but more often they have but one of the two.

A proverb must be venerable. It must bear the sign of antiquity, and, since such signs may be counterfeited by a clever literary man, it should be attested in different places at different times. This last requirement we must often waive in dealing with very early literature, where the material at our disposal is incomplete.

The proverb 'This is what love does and continues to do. It tastes like honey to adults and milk to children' in Jalaluddin Rumi's quotes describes that the sentence 'it tastes like honey to adults and milk to children' is simile. 'like' means as comparison about love and Jalaluddin Rumi's quotes.

Figurative Language is a way of using language in essays, or how an author reveals something that will be put forward. Style (language style) discusses the use of language in certain contexts, by certain authors, and for certain studies.

According to Satoto (2012), style is a way of expressing oneself, whether through language, behavior, dress, and so on. Style is embodiment of the use of language by an author to express images, ideas, opinions, and produce certain effects for the respondent 
as the way it is used (Aminuddin, 1995). As a way using linguistic code, style is relational related with a series of words, sentences, and various possible manifestations of the code linguistic as a sign system.

According to Pradopo (2010) Figurative Language is the arrangement of words that occur because of feelings that arise or live in the heart of the author, which raises a certain feeling in the heart of the reader. That style revives the sentence and gives motion to the sentence. The style of language is to give rise to certain reactions and cause a thought response to reader.

From the statements above, the writer concludes that literature is used to describe anything from creative writing to more technical or scientific works, such as works of poetry, drama, Fiction, and diction.

According to Nurgiyantoro (2018) style (stile) is a way of pronouncing language in prose or an author expresses something he wants to put forward. Stile is characterized by formal linguistic features such as word choice, sentence structure, figurative language forms, use of cohesion, and others. Meanwhile, according (Nurgiyantoro, 2018), argues that the stile element consists of lexical, grammatical, structural stresses, figures of speech, context, and cohesion. Stile elements in literary works in the form of the use of language include all uses of elements of language in the literature itself.

From some of these descriptions, it can be concluded that the style of language is the typical language of the author in literary works. Language style can make literature more lively and varied and can avoid monotonous things that can make the reader bored. Elements of the language style consist of phonology, syntax, lexical, and rhetoric (in the form of characteristics of the use of figurative language, imaging, and parts).

According to Keraf (2016) divides the language style from two aspects, namely the non-language and language aspects. The language style in terms of non-language is divided into seven points, namely based on the author, period, medium, subject, place, audience, and purpose. Based on the language aspect, language style is distinguished based on word choice, tone contained in discourse, sentence structure, and direct or not meaning. The following is a brief description of language style in terms of language.

There are many kinds of figurative language in English. The following are some kinds of figurative language followed by the description from the experts and example: Figurative Language 1 (Simile, Methaphor, Personification).

1. Simile "Simile is used as a means of comparing things that is essentially unlike" (Perrine, 2000) In simile, the Comparison is expressed by the use of some words or phrases, such as 'like', 'as', 'than', 'similar to', 'resembles', 'or seems'. Meanwhile, According to (Keraf, Gorys, 2016) Equations or Similes are explicit comparisons. What is meant by an explicit comparison is that immediately states something is equal to something else.

Example: Truth lifts the heart, like water refreshes thirst.

2. Metaphor: "Metaphor is also figurative language used as a means of comparing things that are essentially unlike. In metaphor, the comparison is implied - that is, 
the figurative language term is substituted for or identified with the literal term (Perrine, 2000)".

Example: she has a heart of stone.

3. Personification: "Personification consist in giving the attributes of a human being to an animal, an object, or a concept. It is really subtype of metaphor, an implied comparison in which the figurative term of the comparison is always a human being (Perrine, 2000)".

Example: where the lips are silent the heart has a thousand tongues.

Figurative Language 2 (Symbol, Allegory)

1. Symbol: "Symbol may be roughly defined as something that means more than what it is (Perrine, 2000)". A symbol means what it is and something more, too. A symbol, that is, functions literally and figuratively at the same time. The symbol is the richest and at the same time the most difficult of the poetic figures. Both its richness and its difficulty result from its imprecision. Although the poet may pin down the meaning of a symbol to something fairly definite and precise, more often the symbol is so general in its meaning that it can suggest a great variety of specific meanings.

Example: "You can't teach an old dog new tricks." (This example is talking not only about dogs but about living creatures of any species and I am therefore speaking symbolically).

2. Allegory: "Allegory is a narrative or description that has a second meaning beneath the surface (Perrine, 2000)". Although the surface story or description may have its own interest, the author's major interest is in the ulterior meaning. Allegory has been defined sometimes as an extended metaphor and sometimes as a series of related symbols. But it is usually distinguishable from both of these. It is unlike extended metaphor in that it involves a system of related comparisons rather than one comparison drawn out. It differs from symbolism in that it puts less emphasis on the images for their own sake and more on their ulterior meanings. Also, these meanings are more fixed.

Example: The story of Adam and Hawa.

Figurative Language 3 (Paradox, Overstatement, Understatement, Irony)

1. Paradox: "A paradox is an apparent contradiction that is nevertheless somehow true (Perrine, 2000)". It may be either a situation or a statement. In a paradoxical statement the contradictional usually stems fromone of the words being used figuratively or in more than one sense. The value of paradox is its shock value. Its seeming impossibility startles the reader into attention and, by the fact of its apparent absurdity, underscores the truth of what is being said.

Example: I feel so lonely in the middle of this crowd. 
2. Overstatement: "Overstatement, or hyperbole, is simply exaggeration, but exaggeration in the service of truth. It is not the same as a fish story (Perrine, 2000) Example: I will die if I don't pass this course.

3. Understatement: "Understatement, or saying less than one means, may exist in what one says and in how one says it (Perrine, 2000).

Example: I apologize, I can only give you snack this afternoon.

4. Irony. "Irony has meanings that extend beyond its use merely as a figure of speech. Verbal Irony, saying the opposite of what one means (Perrine, 2000).

Example: So neat your room looks like a broken ship.

There are three types of irony, there are:

a. Verbal Irony

Is the use of words to mean something different from what a person actually say.

b. Situation Irony

It involves a discrepancy between what is expected to happen and what actually happens. Situation irony occurs when the exact opposite of what is meant to happen, happens.

c. Dramatic Irony

This type irony is popular in works of art such as movies, books, poems and plays. It occurs when the audience is aware of something that the characters in the story are not aware of.

\section{Method}

Researcher takes qualitative research. Bogdan and Taylor through (Moleong, 2019) regulating qualitative evaluation as a procedure research that produces data consists of written or oral words from people and behavior taken. Qualitative research is research which produces analytical procedures that do not use analytical procedures statistics or other quantification methods. Qualitative method is called because of data collected and the analysis is more qualitative (Sugiyono, 2017).

According to Moleong (2019) explains that qualitative research uses qualitative methods, namely observation, interview or document review. This qualitative method is used for several reasons. First, adjusting qualitative methods is easier when dealing with plural reality. Second, this method presents directly the nature of the relationship between researchers and respondents. Third, this method is more sensitive and more adaptable to the many sharpening of the mutual influence on the patterns of values encountered.

Sugiyono (2017) explains that in qualitative research, which becomes the instrument or tool of the researcher himself. Therefore the researcher as an instrument must also be "validated" by further research that provides research that goes into the field. Validation of the researcher as an instrument publishes validation of the understanding of qualitative research methods, mastery of insight into the fields discussed, as well as readiness and provision to launch the field. 


\section{Result And Discussion}

In this research, the writer presents the data which are chosen from Jalaluddin Rumi selected poems and proverb from The Meaningful Life with Rumi book by Jalaluddin Rumi. the writer analyze and identify about kinds of figurative language commonly used by the poems and proverb in Jalaluddin Rumi's quotes. The writer shows the data which are going to be explained specifically as the result of this research, those are also based on the formulation of the research. This researcher takes six themes as a data analysis, therea are: Love, Faith, Hope, Soul, Virtue, Determination Themes.

Table 1 The Kinds of Figurative Language in Love Theme

\begin{tabular}{|c|c|c|}
\hline No. & Corpus & $\begin{array}{c}\text { Kinds of Figurative } \\
\text { Language }\end{array}$ \\
\hline 1. & You dance inside my chest where no one. & Metaphor \\
\hline 2. & $\begin{array}{l}\text { A thousand half-loves must be forsaken } \\
\text { to take one whole heart home. }\end{array}$ & Overstatement \\
\hline 3. & This is love: to fly toward a secret sky, & Overstatement \\
\hline 4. & $\begin{array}{l}\text { I closed my mouth and spoke to you in a } \\
\text { hundred silent ways. }\end{array}$ & Metaphor \\
\hline 5. & $\begin{array}{l}\text { The first condition is that you make } \\
\text { yourself humble as dust and ashes. }\end{array}$ & Simile \\
\hline 6. & $\begin{array}{l}\text { Love is the bridge between you and } \\
\text { everything. }\end{array}$ & Metaphor \\
\hline 7. & $\begin{array}{l}\text { So your heat can raise my soul upward } \\
\text { like a cloud. }\end{array}$ & Simile \\
\hline 8. & $\begin{array}{l}\text { This is how I would die into the love I } \\
\text { have for you. }\end{array}$ & Overstatement \\
\hline 9. & As pieces of cloud dissolve in sunlight. & Simile \\
\hline 10. & $\begin{array}{l}\text { Someone who does not run toward the } \\
\text { allure of love, }\end{array}$ & Overstatement \\
\hline 11. & $\begin{array}{l}\text { This is what love does and continues to } \\
\text { do. } \\
\text { It tastes like honey to adults and milk to } \\
\text { children. }\end{array}$ & Simile \\
\hline 12. & Love is a river. Drink from it. & Metaphor \\
\hline 13. & I choose to love you in silence & Metaphor \\
\hline & I choose to love you in loneliness, & Metaphor \\
\hline & I choose to kiss you in the wind, & Metaphor \\
\hline & I choose to hold you in my dreams, & Metaphor \\
\hline & It is I who makes the garden smile. & Personification \\
\hline
\end{tabular}


Table 2 The Kinds of Figurative Language in Faith Theme

\begin{tabular}{clc}
\hline No. & \multicolumn{1}{c}{ Corpus } & $\begin{array}{c}\text { Kinds of Figurative } \\
\text { Language }\end{array}$ \\
\hline 1. & And he'll make you shine like the sun fall, & \multicolumn{1}{c}{ Simile } \\
\hline 2. & $\begin{array}{l}\text { That which god said to the rose, } \text { And caused } \\
\text { it to laugh in full-blown beauty, }\end{array}$ & Personification \\
& He said to my heart, & \\
\hline 3. & And made it a hundred times more beautiful. & Overstatement \\
\hline 4. & $\begin{array}{l}\text { Though destiny a hundred times waylays } \\
\text { you, }\end{array}$ & Overstatement \\
\hline 5. & But I found the divine within my heart. & Metaphor \\
\hline 6. & $\begin{array}{l}\text { The truth was a mirror in the hands of god. } \\
\text { It fell, and broke into pieces. }\end{array}$ & Overstatement \\
\hline 7. & You are the truth from foot to brow. & Overstatement \\
\hline 8. & $\begin{array}{l}\text { Only the hand of god,can remove the } \\
\text { burdens of your heart. }\end{array}$ & Metaphor \\
\hline 9. & Take time like the river that never goes stale. & Simile \\
\hline 10. & $\begin{array}{l}\text { And see a hundred different ways to be with } \\
\text { me. }\end{array}$ & Overstatement \\
\hline 11. & I have lived on the lip of insanity, & Overstatement \\
\hline 12. & He who is the eye and the Sun of heaven, & Metaphor \\
\hline 13. & $\begin{array}{l}\text { He who is the soul and the universe that } \\
\text { births souls. }\end{array}$ & Metaphor \\
\hline & &
\end{tabular}

Table 3 The Kinds of Figurative Language in Hope Theme

\begin{tabular}{|c|c|c|}
\hline No. & Corpus & $\begin{array}{l}\text { Kinds of Figurative } \\
\text { Language }\end{array}$ \\
\hline 1. & $\begin{array}{l}\text { Anything you lose comes round in another } \\
\text { form. }\end{array}$ & Metaphor \\
\hline 2. & $\begin{array}{l}\text { Hear blessings dropping their blossoms } \\
\text { around you. }\end{array}$ & Personification \\
\hline 3. & $\begin{array}{l}\text { These pains you feel are messengers. Listen } \\
\text { to them. }\end{array}$ & Personification \\
\hline 4. & $\begin{array}{l}\text { It shakes the yellow leaves from the bough of } \\
\text { your heart, }\end{array}$ & Metaphor \\
\hline 5. & $\begin{array}{l}\text { When you feel you cannot even bear one } \\
\text { more minute, }\end{array}$ & Overstatement \\
\hline 6. & The breeze at dawn has secrets to tell you. & Personification \\
\hline 7. & Drum sound rises on the air, & Overstatement \\
\hline 8. & $\begin{array}{l}\text { The two as beautifully balanced and } \\
\text { coordinated as birds's wings. }\end{array}$ & Simile \\
\hline
\end{tabular}


Table 4 The Kinds of Figurative Language in Soul Theme

\begin{tabular}{|c|c|c|}
\hline No. & Corpus & $\begin{array}{l}\text { Kinds of Figurative } \\
\text { Language }\end{array}$ \\
\hline 1. & I want to sing like the birds sing, & Simile \\
\hline 2. & Be like the sun for grace and mercy. & Simile \\
\hline 3. & Be like the night to cover others' faults. & Simile \\
\hline 4. & Be like running water for generosity. & Simile \\
\hline 5. & Be like death for rage and anger. & Simile \\
\hline 6. & Be like the earth for modesty. & Simile \\
\hline 7. & Appear as you are. Be as you appear. & Simile \\
\hline 8. & The heart has a thousand tongues. & Personification \\
\hline 9. & $\begin{array}{l}\text { Like a sculptor, if necessary, Carve a friend } \\
\text { out of stone. }\end{array}$ & Simile \\
\hline 10. & $\begin{array}{l}\text { Put yourself behind my eyes and see me as I } \\
\text { see myself, }\end{array}$ & Simile \\
\hline 11. & $\begin{array}{l}\text { The only lasting beauty is the beauty of the } \\
\text { heart. }\end{array}$ & Metaphor \\
\hline & As you live deeper in the heart, & Simile \\
\hline & $\begin{array}{l}\text { The heart knows a hundred thousand ways to } \\
\text { speak. }\end{array}$ & Personification \\
\hline & Recognize the luminosity of souls. & Overstatement \\
\hline & The soul has been given its own ears to hear, & Personification \\
\hline & There is a moon inside every human being. & Metaphor \\
\hline 17. & Sunlight fell upon the wall, & Personification \\
\hline
\end{tabular}

Table 5 The Kinds of Figurative Language in Virtue Theme

\begin{tabular}{|c|c|c|}
\hline No. & Corpus & $\begin{array}{l}\text { Kinds of Figurative } \\
\text { Language }\end{array}$ \\
\hline 1. & Truth lifts the heart,Like water refreshes thirst. & Simile \\
\hline 2. & $\begin{array}{l}\text { Moonlight floods the whole sky from horizon } \\
\text { to horizon; }\end{array}$ & Overstatement \\
\hline 3. & Your heart is the size of an ocean. & Overstatement \\
\hline 4. & $\begin{array}{l}\text { The ground's generosity takes in our compost } \\
\text { And grows beauty! Try to be more like the } \\
\text { ground. }\end{array}$ & Simile \\
\hline 5. & And be silent like an oyster shell, & Simile \\
\hline 6. & The heart has a hundred tongues. & Personification \\
\hline 7. & Listen with ears of tolerance! & Metaphor \\
\hline 8. & Speak with the language of love. & Metaphor \\
\hline 9. & $\begin{array}{l}\text { Your hands and your feet say what you have } \\
\text { done. }\end{array}$ & Personification \\
\hline 10. & $\begin{array}{l}\text { Every need brings in what's needed. } \\
\text { Pain bears its cure like a child. }\end{array}$ & Simile \\
\hline 11. & She can tie knots in your chest. & Metaphor \\
\hline 12. & Listen to the ocean. & Personification \\
\hline 13. & The glowing jewel says, & Personification \\
\hline
\end{tabular}


Table 6 The Kinds of Figurative Language in Determination Theme

\begin{tabular}{llc} 
No. & \multicolumn{1}{c}{ Corpus } & $\begin{array}{c}\text { Kinds of Figurative } \\
\text { Language }\end{array}$ \\
\hline 1. & You feel a river moving in you, a joy. & Metaphor \\
\hline 2. & Now is the time to see the sunlight dancing, & Personification \\
\hline 3. & $\begin{array}{l}\text { The sunlight dancing As one with the } \\
\text { shadows. }\end{array}$ & Simile \\
\hline 4. & I am a carpenter of my own soul. & Metaphor \\
\hline 5. & On this path let the heart be your guide, & Metaphor \\
\hline 6. & I have searched all over the world, & Overstatement \\
\hline 7. & Touch the sun, and immerse in the sea. & Metaphor \\
\hline
\end{tabular}

There are many figurative languages which Jalaluddin Rumi put in his quotes. There are sentences in Jalaluddin Rumi's quotes which related figurative language. The figurative language that analyzed, as follows: metaphor, personification, overstatement, and simile. The total figurative language which find out in Jalaluddin Rumi's quotes are 75 from 60 quotes, below are the details:

Table 7 Total of Figurative Language

\begin{tabular}{ccc}
\hline No. & Kind of Figurative Language & Total \\
\hline 1. & Metaphor & 23 \\
\hline 2. & Simile & 22 \\
\hline 3. & Overstatement & 16 \\
\hline 4. & Personification & 14 \\
\hline
\end{tabular}

From the table above, the writer has found that the most of dominant figurative language which is utilized in Jalaluddin Rumi's quotes in the book of The Meaningful Life with Rumi by Jalaluddin Rumi is metaphor with the total 23 statements.

After that, the writer has found the keywords to identify figurative language in the quotes in the book The Meaningful Life with Rumi by Jalaluddin Rumi. As follows:

a. Metaphor can be identified by looking the verb in quotes. If the phrase is always comparing meaning explicitly because of the similarity in nature between two objects. It is a semantic diversion based on the similarity of perception of meaning.

b. Simile can be identified by looking the verb in quotes. If the phrase is always comparison of meaning explicitly, that is comparing two things with the connecting word such as: 'like', 'as', 'than', 'similar to', 'resembles', or 'seems'.

c. Overstatement or hyperbole can be identified by looking the verb in quotes. If the phrase is always contains an exaggeration, exaggerating things.

d. Personification can be identified by looking the verb in quotes. If the phrase is always which depicts inanimate objects or inanimate objects as if they have human characteristics. 
Imam Soekarno Putra and Anita Puspitasari

\section{Conclusion}

After analyzing Jalaluddin Rumi's quotes, the writer at first finds many particular ways complex sentences to express the actual meaning, the writer then comes to conclusion. Therefore, the writer takes conclusions that has found total figurative language 75 statements from 60 quotes based on each theme that are love theme, faith theme, hope theme, soul theme, virtue theme and determination theme, and there are 23 statements of metaphor, 22 statements of simile, 16 statements of overstatement, and 14 statements of personification. Therefore, the writer has conclude that the most dominant of figurative language which is utilized in Jalaluddin Rumi's quotes in the book of The Meaningful Life with Rumi by Jalaluddin Rumi is metaphor with the total 23 statements. 


\section{BIBLIOGRAFI}

Aminuddin. (1995). Stilistika: pengantar memahami bahasa dalam karya sastra. IKIP Semarang Press.

Delahunty, Gerald P., \& Garvey, James J. (2010). The English Language from sound to sense. The WAC Clearinghouse. parlor press, fort Collins, Colorado.

Keraf, Gorys. (2016). Diksidan Gaya Bahasa. Jakarta: PT Gramedia Pustaka Utama.

Mieder, Wolfgang. (2004). Proverbs: A handbook. Greenwood Publishing Group.

Moleong, Lexy J. (2019). Metodologi penelitian kualitatif.

Nurgiyantoro, Burhan. (2018). Teori pengkajian fiksi. UGM press.

Perrine, L. (2000). Sound and Sense. An Introduction to Poetry. Sixth Addition. Harcourt: Brave Jovanovich.

Pradopo, RahmatDjoko. (2010). Pengkajian Puisi (Eleventh Edition). yogyakarta: GadjahMada University Press.

Satoto, Soediro. (2012). Stilistika. yogyakarta: Ombak.

Sugiyono. (2017). Metode Penelitian Kuantitatif, Kualitatif, dan R\&D. Bandung: CV. Alfabeta.

Wellek, Rene, \& Warren, Austin. (1989). Teori Kesusastraan, terj. Melani Budianta. Jakarta: Gramedia. 